\title{
APPRECIATION IN VALUE AS INVESTED CAPITAL UNDER THE EXCESS PROFITS LAW
}

\author{
Charles McCamic \\ West Virginia Bar
}

The entry of the United States into the World War brought at once in its train the pressing questions of raising revenue to meet the war expenses. Part of the funds necessary was raised by the various issues of Liberty Bonds, and the rest was raised by a series of internal taxes. As to the latter much reliance was placed upon the income tax and so-called excess profits tax. The report of the Committee on War Finance estimates that for the year IgI8 the receipts from these two sources were approximately seventy-three per cent of the total income derived from taxation. ${ }^{1}$ The operation of the law, considered in a broad way, was a success. Yet, after praising the result obtained, the point is reached where just criticism begins. ${ }^{2}$ The Act of Congress of February 24, 1919, deals in part with the subject "War Profits and Excess Profits Tax.", As now written and enacted the excess profits tax applies only to corporations. ${ }^{4}$ The Act of October 3, I9I7, applied in addition to individuals and to partnerships. In this respect the present act is simpler in its workings than the former act. The excess profits $\operatorname{tax}$ is the invention of the war, and is an ingenious expedient

\footnotetext{
${ }^{1}$ Report of Committee on War Finance (IgI9) 9 AM. EcoN. REv. SUPP. 2, at p. 4: "For the fiscal year I9I8 the receipts from these sources were approximately $\$ 2,840,000,000$, which was over 73 per cent of the total income derived from taxation ... it is evident that they were the mainstay of our war finances."

${ }^{2}$ Edwin R. A. Seligman, The War Revenue Act (19I8) 33 Por. Scr. Quar. I 32: "The third and most important drawback is the unfortunate principle adopted in the elaboration of the excess-profits tax. ... The law will in all probability be found to be almost unworkable."

Professor Robert Murray Haig, The Reverne Act of 1918 (Igrg) 34 Por. ScI. Quar. 369, 382: "The Excess Profits Tax Law of 1917 was probably as deservedly unpopular as any tax measure could well be . . . It was unfair in its scope, uneven in its application, and so poorly drafted that only by the boldest administrative action could it be made to function at all."

Hon. Carter Glass, Secy. of Treasury, Report to Congress (Dec. I9I9) : "Still more objectionable is the operation of the excess profits tax in peace times."

"Title III, secs. 300-337. The Act was styled "An Act to Provide Revenue and for other purposes," in contradistinction to the Act it amended, that of October 3, rgI7, which was styled "An Act to Provide Revenue to defray War Expenses and for other purposes."

- Act of February 24, 1919, sec. 301.
} 
devised to reach, not profits resulting from war industries, but to tax the excess during the war over ordinary profits. ${ }^{5}$

It is the purpose of this paper to discuss the puzzling phrase, "invested capital," as defined in section 326 of the present act ${ }^{8}$ : “... (3) paid in or earned surplus and undivided profits, not including surplus and undivided profits earned during the year." For all present purposes this phrase and that in the Act of October 3, I9I7, are the same. " The important point is the computation of "capital," the Act using the term "invested capital." The greater the amount of "invested capital" as compared with a given income, the smaller will be the percentage and tax.

It will be noted at once that the Act lacks definition. "Paid in or earned surplus and undivided profits," are not defined, either in the Act of October 3, I9I7, nor in the present law. This lack of definition was attempted to be supplied by action of the Treasury Department, and accordingly, as early as November 8, I9I7, Daniel C. Roper, Commissioner of Internal Revenue, sent throughout the country a request for suggestions as to the methods of computing the amount to be used as invested capital. ${ }^{8}$ So too, a substantially similar statement was made by Secretary McAdoo himself in announcing the personnel of the Excess Profits Advisory Board, appointed under the Act of October 3 , 1917. One of the net results of this action of the

${ }^{5}$ (19r9) 9 AM. Econ. REv. Supr. 2, at p. 16: "The Treasury recommended . . . an alternative system . . . by which two taxes should be computed, one upon the present excess profits principle and the other upon the war profits principle adopted by Great Britain, which bases the tax upon the excess of the profits realized in the taxable year above the average profits realized during a series of years prior to the war; with a provision that the higher of the two amounts thus determined should be the amount of the tax actually assessed." See also Plehn, War Profits and Excess Profits Taxes (1920) Io Asr. Econ. REv. 283, 285: "The war profits tax which soon evolved into the excess profits tax, was first proposed in I9r5 in Denmark and Sweden." By I9I7, thirteen countries had been invaded by this tax.

"Act of February 24, I919, sec. 326: "(a) That as used in this title the term "invested capital" for any year means (except as provided in subdivisions (b) and (c) of this section): (I) Actual cash bona fide paid in for stock or shares. (2) Actual cash value of tangible property, other than cash, bona fide paid in for stock or shares at the time of such payment ... (4) Intangible property bona fide paid in for stock or shares prior to March 3, 1917 ... (5) Intangible property bona fide paid in for stock or shares on or after March 3, 1917. . ."

${ }^{7}$ See Act of October 3, 19I7, sec. 207: “... (3) Paid in or earned surplus and undivided profits used or employed in the business, exclusive of undivided profits earned during the taxable year."

8 "Treasury Department, Washington, November 8, I9r7, Sir: ... You are particularly requested to outline the method of computing 'invested capital' under sections 201, 204, 207, and 208 of the Excess Profits Tax Law, which would be most practicable and accurate. Illustrations in actual cases showing the application will be gladly received. .."

'Official Bulletin, Nov. 14, I9r7 (the government daily publication). 
Treasury Department is the general exclusion of appreciation from the value of capital assets as invested capital. ${ }^{10}$ Under the present Act the Treasury Department has ruled that "the fair market value of the assets as of March I, I9I3, has no bearing on invested capital."11

In passing the I9I9 Act, Congress has written into the new law some of the more important of the administrative rulings which the Treasury Department evolved in efforts to make the I9I7 Act reasonable and equitable. ${ }^{12}$ At the time of the passage of the present Act the Department regulation discussed here had been evolved, and the claim is made for it that it now has the force of law by reason of the remarks of Senator Simmons, Chairman of the Senate Finance Committee, when the Senate draft of the present Act was presented. ${ }^{13}$

It is interesting to note that an amendment was offered in the House of Representatives on September 3, 1918 , to section 326 , to exclude the increase in value above the original cost until such increase was actually realized by sale. ${ }^{14}$ This amendment passed the House but was struck out by the Senate Finance Committee on December I5, 1918, and the Act as finally passed on February 24, I9I9, does not contain it.

Notwithstanding these rulings of the Treasury Department and the remarks of Senator Simmons, it is believed that the question of what constitutes invested capital under the phrase "paid in or earned surplus and undivided profits" is not foreclosed against the taxpayer. An effort has been made to have the Court of Claims hold to that effect, but that Court has upheld the regulation. ${ }^{15}$

${ }^{10}$ U. S. INT. Rev. Regulations 4I (r9I7) art. 42: “ ... If value appreciation of a kind not subject to income tax, (other than that allowed under article 55) has been taken up in the accounts a deduction must be made in respect of such appreciation so taken up..."

${ }^{11}$ U. S. INT. Rev. REGULATIONS 45 (I918) arts. 83I, 838 .

${ }^{12}$ See Haig, op. cit. note 2 , at p. 383 .

${ }^{13}$ Report of the Committee on Finance, U. S. Senate (S. Rept. 617, 65th Cong., 3d sess.) II: "Speaking generally, assets are valued, for the purpose of determining invested capital, at the price paid in acquiring them, without recognition of subsequent appreciation. Weighty arguments have been presented in favor of abandoning this rule, and valuing property acquired before March 1 , 1913, as of that date. But the Committee believes that such a method would be impracticable; that it would impose upon the Treasury Department the impossible task of valuing nearly all of the durable property of the country as of a date nearly six years in the past. The present statutory rule works well in a large majority of cases. The remaining cases in which it works injustice, can and should be cared for by adequate relief provisions which the Committee has carefully formulated and recommends."

${ }^{14}$ H. R. 12863 .

${ }^{15}$ This case is not yet reported; see (1920, Ct. C1.) 38 Treas. Dec. (August 5, I920) 19. ... "The court's conclusions are: (I) That the act in question (40 Stat., 306) undertakes to define "invested capital" and the averments of the petition cannot be said to bring the plaintiff's case within the definition of section 207. (2) That the increase in value of plaintiff's ore lands, which was first declared to be surplus, and afterwards treated as the basis of a stock 
At the time of the passage of the Act of February 24, r9r9, and of the Act of October 3, I917, each using the phrase "paid in or earned surplus and undivided profits," there was no fixed, definite terminology by which the phrase "earned surplus and undivided profits" might be said to exclude value appreciation in the estimation of capital assets. It remained for the Treasury Department to exclude such value by regulations. Such exclusion cannot be pitched upon current knowledge of accounting as then existing. It is clear that the terms as then used in that science included actual value appreciation. ${ }^{16}$ In fact, the term "surplus" and "undivided profits" are terms of interchangeable meaning. ${ }^{17}$ And surplus usually means surplus of assets over liabilities, and corporate profits means profits available for dividends. ${ }^{18}$

Stress is placed upon the apparent uniform meaning and use of terminology in this well-known science of economics and finance, because it is a well-recognized rule that language in a statute is to be given its ordinary meaning, ${ }^{10}$ when such construction will not defeat the manifest intention of the legislating body.

But the rule of construction of the statute need not be exclusively drawn from that ordinary meaning given in economics and finance. Resort may be had successfully to the accepted definitions of the courts, including no less authority than the Supreme Court of the United States. These decisions uniformly recognize that appreciation in value

dividend, did not thereby become earned surplus or individual profits or invested capital within the meaning of the act of $1917 .{ }^{\circ}$ The stock dividend added nothing to, and took nothing from, the corporation's invested capital. (3) That the inequalities, which can arise in the application of the statnte to particular cases, can not be corrected by judicial construction, where the enactment is otherwise valid. (4) That where the act is ambiguous or uncertain, the construction of it by the administrative officers charged with its execution is entitled to great respect."

${ }^{18}$ See for definitions of appreciation and surplus, Year Book (Ig09, Am. Ass. of Pub. Acc.) I6r, 179; Year Book (Igrr, Am. Ass. of Pub. Acc.) I24; Arthur Lowes Dickenson, address delivered Sept. 27, I904, before the Congress of Accountants at St. Louis on the subject, The Profits of a Corporation ("In the widest possible view profits may be stated as the realized increment in value of the whole amount invested in an undertaking; and conversely loss is the realized decrement in such value. ... In other words every appreciation of assets is a profit, and every depreciation a loss. . ."); 22 Greendlinger, Financial and Business Staternents, Ig6.

${ }^{17}$ See R. J. Bennett, Corporation Accounting (I9I7) 334 sec. 29I ; Joseph Paul Esquerré, The Applied Theory of Accounts (I9r7) 30; Joseph J. Kline, Elements of Accounting, 174, 254; Samuel F. Racine, Accounting Principles, IgI.

${ }^{18}$ Arthur Lowes Dickinson, Accounting Practice and Procedure (IgI7) 62.

${ }^{19}$ Levy v. McCartee (1832, U. S.) 6 Pet. 102, Iro, by Mr. Justice Story: "The legislature must be presumed to use words in their known and ordinary signification unless that sense be repelled by the context"; Eisner v. Macomber (1920) 252 U. S. $189-, 40$ Sup. Ct. 189 , 193: words are to be construed "as used in common speech." 
of capital assets constitutes value, for purposes of taxation, ${ }^{20}$ stock dividends, ${ }^{21}$ capital additions, ${ }^{22}$ sale of assets, ${ }^{23}$ for rate-making purposes, ${ }^{24}$ and for condemnation purposes. ${ }^{25}$ A dividend is only to be declared out of profits. "Accumulated profits," a term occasionally used, is another method of speaking of "surplus." 26

As earned, profits may be distributed. Are we to speak of another class of profits as "acquired," as distinguished from "earned" or "paid in"? And after all what boots it by what method the profits are earned? Until actually severed, the corporation has full and complete title to them and dominion over them, and the power to treat them as capital and use them as such in its business. ${ }^{27}$ The statute in question does not require the earnings of a corporation to be severed from its other assets; so long as the particular item comes within the designation as either earned surplus or undivided profits, the right to treat it as invested capital is preserved.

Value appreciation certainly represents a "profit." If not an earning, what is it? Value exists, against which the corporation can issue dividends, and if it is not a profit, it is hard to conceive in what class to place it. ${ }^{28}$ A dividend may be in stock, and yet represent profit. Profits may be distributed as earned. They may be in whole or in part retained and utilized for the corporate advantage. They may never be distributed but permanently used in the business. ${ }^{29}$ "Profits" is a term of decision in the Supreme Court of the United States. ${ }^{30}$ They con-

${ }^{20}$ People v. Coleman (1891) 126 N. Y. 433, 27 N. E. 8r8, 12 L. R. A. 762, note.

${ }_{21}$ Minot v. Paine (1868) 99 Mass. Ior; McGinnis v. O'Conner (1909) III Md. 695, 72 At1. 6r4; 2 Cook, Corporations (7th ed. r913), sec. 536; Williams v. Western Union Tel. Co. (1883) 93 N. Y. 162, I88: “. . . Its capital stock may be reduced below the amount limited by its charter; but whatever property it has up to that limit must be regarded as its capital stock. When its property exceeds that limit, then the excess is surplus. Such surplus belongs to the corporation and is a portion of its property, and, in a general sense, may be regarded as a portion of its capital, but in a strictly legal sense it is not a portion of its capital, and is always regarded as surplus profits."

${ }^{22}$ Towne v. Eisner (rg18) 245 U. S. 418, 38 Sup. Ct. 158; Southern Pacific v. Lowe (I918) 247 U. S. 330,38 Sup. Ct. 540 ; Lynch v. Hornby (I918) 247 U. S. 339, 38 Sup. Ct. 543 ; Doyle v. Mitchell Bros. Co. (I9r8) 247 U. S. I79, 38 Sup. Ct. 467 (stumpage case).

${ }^{23}$ Mangham v. State (1912) in Ga. App. 440, 75 S. E. 508.

"Re Hinton Water Light and Supply Co. (19I9, W. Va. Pub. Ser. Com.) P. U. R. IgIgD, 467.

${ }^{25} 2$ Lewis, Eminent Domain (3d ed. I909) sec. 706 and cases cited.

${ }^{26}$ Gibbons v. Mahon (I890) 136 U. S. 549, 10 Sup. Ct. 1057.

${ }^{27}$ Security Trust Co. v. Rammelsburg (I918) 82 W. Va. 70I, 97 S. E. 122.

${ }^{23}$ See Hite's Devisees $v$. Hite's Executors (1892) $93 \mathrm{Ky} .257,20 \mathrm{~S}$. W. 778.

${ }^{20}$ Hemenway v. Hemenway (I902) I8I Mass. 406, 63 N. E. 9I9; see also Eisner v. Macomber, supra note Ig.

${ }^{20} \mathrm{Mr}$. Justice Jackson in Mobile and Ohio Ry. v. Tennessee (1894) I53 U. S. 486, 497, I4 Sup. Ct. 968, 97x: "The term 'profits,' out of which dividends above can properly be declared, denotes what remains after defraying every expense, including loans falling due, as well as the interest on such loans." 
stitute the clear gain of any business venture after deducting the capital invested in the business, the expenses incurred in its conduct, and the losses sustained in its prosecution. ${ }^{31}$

If the ordinary meaning of language as used and known in terms of finance, economics, and law, is not to control the construction of the act, and it is to be assumed that the language is capable of a fluidity of construction, still the taxpayer must be favored by the courts. ${ }^{32}$ All the revenue acts of Congress are to be looked to as parts of one system. $^{33}$

Let us suppose that a corporation is formed with five thousand shares of capital stock of the par value of one hundred dollars each. In I900 it acquires for $\$ 100,000$, ore lands, which gradually increase in value, until in I9I2 bona fide offers of purchase are made to it at a price of $\$ 1,000,000$. Instead of selling, the corporation, prior to March I, I9I3, increases its authorized capital stock and then capitalizes the value appreciation, by declaring a stock dividend of $\$ 900,000$. In making its return of income and excess profits tax for 1917 , the return of invested capital of the corporation includes the $\$ 900,000$ appreciation against which the stock was issued. The Treasury Department under its regulations strikes from the invested capital of the corporation the $\$ 900,000$ appreciation, notwithstanding that the value exists representing the $\$ 900,000$.

There are men now living who purchased Iowa farms fifty years ago for no more than three dollars per acre, which are now worth five hundred dollars per acre. To say that such an original purchaser of one hundred acres must treat his invested capital as three hundred dollars, while a neighbor who has an identical farm for which he paid five hundred dollars per acre, can treat his invested capital as $\$ 50,000$, is to argue that if the heirs of the original purchaser of Manhattan Island still held it, the total invested capital would be $\$ 24$, on the theory that that was the sum paid to the Indians.

The "appreciation" in the hypothetical corporation case became surplus and was capitalized by the declaration of a stock dividend. The surplus was available for dividends, and when by corporate action it became part of the corporate capital, it was withdrawn as a fund out of which dividends could thereafter be paid. Dividends are not permitted to impair capital. So long as there is a surplus, there are funds available for dividends, whether that surplus comes from appreciations in value or from business operations of the corporation. The declaration of a stock dividend takes out of surplus what was before surplus

\footnotetext{
" Park v. Grant Loco. Works (1885) 40 N. J. Eq. I14, 3 Atl. 162; 4 Thompson, Corporations (2d ed. I9II) sec. 5307; 2 Cook, Corporations (7th ed. I9I3) sec. 536 .

${ }^{2}$ See Gould v. Gould (1917) 245 U. S. I5I, r53, 38 Sup. Ct. 53.

${ }^{33}$ Black, Income Taxation (I9r3) secs. 30, 3I and cases cited; Wetmore $v$. Markoe (1904) I96 U. S. 68, 25 Sup. Ct. 172.
} 
and puts it in the capital account, and a permanent addition to the capital is the result. "Once capital, always capital." Does it become "invested capital" to be included as a part of the amount on which the corporation may figure its 7,8 , or 9 per cent. of deduction? A distinction may be apparent between the case of capitalized appreciation, and appreciation not capitalized. In the former case it has been carried to and through the surplus account; in the latter it may never have reached the surplus account, although in a recent case in the Supreme Court the appreciation was not entered on the books. ${ }^{33 a}$

The hypothetical case differs only in its details from that of many corporations now engaged in business in the United States. Especially is this true with the so-called "close" corporations, begun years ago with nominal capitals, which by successful business judgment and sound principles have become of great value at the present time. How frequently in the United States have corporations begun business with small capitals, which, because "the enterprise was happily chosen and skillfully conducted," ${ }^{34}$ have increased in value from time to time through additions by way of appreciation of capital assets, against which years ago, perhaps, stock dividends have been declared? Yet, if the regulations of the Treasury Department are upheld, these corporations are subject to the rule that the value appreciations must be excluded or, as stated in the regulations, "invested capital within the meaning of the statute is the capital actually paid in to the corporation by the stock-holders, including the surplus and undivided profits, and is not based upon the present net worth of the assets." ${ }^{35}$

When one comes to analyze the tax burdens placed upon corporations by this excess profits law, he finds that certain kinds of appreciation in value are recognized and allowed by the Treasury Department regulations. If the taxpayer has gone through a form of procedure recognized by the Treasury Department, the value of the "value appreciation" in the capital assets is allowed as an item upon which the deduction can be claimed. A few of the permissible methods under the regulations are given in the examples following, in each of which it is believed that appreciation is allowed under the Act of Congress as construed by the Treasury Department:

I. If when the ore lands (in the hypothetical case) are acquired, the company has gone through the process of issuing preferred stock to the amount of their actual cash value at that time, to wit, $\$ 100,000$, and in addition has issued watered stock to the amount of $\$ 900,000$, and if by January $\mathrm{I}, \mathrm{I9} \mathrm{I} 4$, there has been an appreciation of $\$ 900,000$, this appreciation can be included in invested capital. Now if the issue of this additional stock is postponed until rgr2, when the appreciation has

${ }^{*}$ See Doyle v. Mitchell Bros., supra, note 22.

s People v. Coleman (1891) 126 N. Y. 433, 443, 27 N. E. 818, 820.

ss U. S. INT. Rev. Regulations 45 (19I8) art. 831 . 
been demonstrated, and then is struck out as invested capital, a peculiar kind of high financing is favored.

2. If the company has sold the ore lands for $\$ 1,000,000$, of course the appreciation could be included, for in that case appreciation becomes "earned surplus." But it is evident that the mere sale does not create the surplus. The profit has been accruing over a long period of years. Conversion into cash does not create the profit, and in fact a conversion into cash is not necessary.

3. If the lands have been traded for other ore lands precisely similar, which had a market value of $\$ 1,000,000$, then this is a realization of the profit in the original ore lands, and the invested capital on account of the substituted ore lands would be $\$ 1,000,000$.

4. If the company has distributed these lands to its shareholders acre by acre in the year I912, and the stockholders have then re-conveyed those ore lands to the company in payment for $\$ 1,000,000$ of stock, this again would constitute a payment in of these lands in exchange for shares, and therefore the company could claim that amount of invested capital.

5. If at the time of the stock dividend in I9I2, the lawyers in charge of the matter have advised the Company that because of technical difficulties it should go through the form of chartering a new company to which all assets would be transferred, the stockholders of the old company to own pro rata the shares of the new company, then this, too, would cause the new company to have an invested capital based upon the market value of the ore lands.

6. If in Igoo the individual stockholders have acquired these ore lands at $\$ 100,000$ and turned them into the company for $\$ 1,000,000$, par value of its stock, even though in I900 the $\$ 100,000$ represented only the property's then market value or worth, still since that property so exchanged or paid in for stock on March I, I9I3, was worth $\$ 1,000,000$, the latter figure and not the $\$ 100,000$ has to be used (be usable) in the calculation of the Company's "invested capital."s6

To Senator Simmons' remarks in the Senate of the United States that "speaking generally, assets are values for the purpose of determining invested capital at the prices paid in acquiring them, without recognition of subsequent appreciation," ${ }^{37}$ the answer is that his statement is only partly true. There then existed approved regulations by which

These examples may be emphasized by reference to an article by Prof. T. S. Adams of Yale University, former Chairman of the Excess Profits Tax Advisory Board of the Treasury Department, Needed Tax Reform in the United States in the New York Evening Post (reprinted I920, especially at p. 8). Another writer has similar comments to make. A. A. Ballantine, Some Constitutional Aspects of the Excess Profits Tax (I920) 29 YALE LAW Journal, 625, 626: "The method adopted in the statute operates to produce for enterprises similarly circumstanced in every respect, except that of cash or cash value paid or left in against stock, tax burdens which are materially different."

${ }^{37}$ Supra note $\mathrm{J} 3$. 
subsequent appreciation was recognized as invested capital, for the purpose of the deduction allowed in the Excess Profits Tax Law. Some of these devices have been mentioned here, and it becomes apparent that Professor Adams is correct in saying that "the tax thus depends largely upon the mere form and manner of organization, upon chance and accident; it is unequal and capricious, it penalizes conservative finance, and it rewards stock-watering. ... It is a common thing for a million dollars or more in taxes to turn on some fine-spun distinction, about which nearly as much can be said upon one side as upon the other."

The Treasury Department, however, by regulation has attempted to retain for itself the right in particularly difficult cases to afford relief against its own regulation excluding appreciation, by reconstructing "invested capital." This is also a concession by the Department that the Act does not warrant the exclusion of appreciation. There is no reason for distinction of classes in taxpayers, for whether the Act includes or excludes value appreciation, the harshness of its operation is not to be set aside by the Treasury Department when its exercise rests upon no rule of certainty, and involves the exercise of discretion by administrative officers. ${ }^{38}$

The form of the transaction should not be the criterion to establish whether or not appreciation is to be included as invested capital.

The exemption is supposedly based on the taxpayer's invested capital; this means, of course, the taxpayers capital.

If by its definition of the term, or otherwise, Congress has sought to differentiate between portions of that capital-the part earned from manufacturitg activities, for example, from the part, if any, accrued from other sources-it has made a classification which amounts in effect to a direct tax upon that part of the taxpayer's capital excluded by such differentiation. This results in a tax upon property because of ownership, which requires apportionment under the Constitution. ${ }^{38}$

\footnotetext{
"See Committee on War Finance, (IgIg) 9 AM. Econ. REv. Sưp. 2, at p. 22 : "In its published regulations the Treasury Department after enumerating various cases to which section 210 was clearly applicable, held that the section might be invoked in cases where 'the invested capital is seriously disproportionate to the taxable income'; which cases might arise through 'the realization in one year of the earnings of capital unproductively invested through a period of years or of the fruits of activities antedating the taxable year,' as well as through inability to allow properly for 'amortization, obsolescence, or exceptional depreciation' of war plants. Thus the section was made applicable to cases in which the invested capital could be determined not only with satisfactory, but with deadly accuracy, a somewhat extraordinary result. From every practical foint of view, however, the ruling was extremely fortunate, because it enabled the Department to give relief in cases where the power to tax involved not only the "power to destroy" but the actual exercise of that power. It appears that under this interpretation of section 210 the department has reconstructed the capital of no inconsiderable number of concerns with a view to reducing "to a reasonable figure the taxable income in excess of the authorized deduction." ". Pollock v. Farmers Loan \& Trust Co. (1895) I58 U. S. 60I, I5 Sup. Ct. 912;
} 
Again, by making a distinction between taxpayers because of the sources from which their property (capital) is derived, and levying a heavier tax on one than on the other, the basis of cost is an unreasonable classification of taxpayers, void under the due process clause of the Fifth Amendment. $39 \mathrm{a}$

These matters may perhaps be made clear by an illustration. Bank $A$ in New York began business in 1840 ; it acquired a location at the corner of Broad and Wall Streets for which it paid \$100,000; by rgr7 its location over the period of years had increased in value to $\$ 1,000,000$; the land was taxed to it at that sum; similar pieces of property in the vicinity had sold at that figure or more. Bank B began business in I9I6 in New York and acquired a site near that of the former and expended $\$ 1,000,000$ in so doing. To say under these circumstances that for purposes of "invested capital" the capital of A must be taken at $\$ 100,000$ and that of $B$ at $\$ 1,000,000$ is obviously such an arbitrary discrimination as at once to make its unreasonableness apparent as a classification of the taxpayers. It means further that $\$ 900,000$ of the Capital of bank $A$ is to be disregarded and the full earnings of $\$ I, 000,000$ of bank $B$ are not to be taxed. This in effect is a direct tax requiring apportionment.

Earned surplus and undivided profits may consist of value increment, as well as revenue from operations. "Earned" is merely contrasted with "paid in" in the statute. An increment in value is not "paid in," but that does not say that it is not earned; it is "earned" in contemplation of law as well as of business, if in fact it exists and is not paid in. This seems so obvious that a mere statement should suffice. The ordinary contrasting terms as applied to surplus are "paid in" and "earned," the former applying to something the share holder has himself contributed (as he did his capital), and the latter applying to all other surplus and not so contributed. The latter may be derived from the operations of the company's ordinary business, from the sale of its capital assets or part thereof, or from many other sources. To say that bona fide actual appreciations in a company's properties may be counted in calculating its earned surplus ONLY when that appreciation has been determined by a sale of the properties, is to beg the question. The sale is only a detail, a method of determining the fact; the fact, however, is and remains the fact, whether so determined or otherwise demonstrated. The idea of "an unearned increment" does not bear upon the question at all; that would be equally present whether there were a sale or not, and, as is conceded, if there be a sale, the realized enhancement is "earned" whether the whole appreciation over cost be due to company activity, or is wholly due to the growth of the community or the growing scarcity of the kind of property, with all of which the Company had nothing to do. It is obvious from this, that the

${ }^{30}$ Gast E Co. v. Schneider (IgI6) 240 U. S. 55, 36 Sup. Ct. 400. 
use of the words "earned surplus" in the statute are not intended to have a meaning different from the usual one, and they are usually used to mean all surplus not paid in, and hence include bona fide property appreciation taken up in the accounts of the taxpayer if actually then existing. There is no exclusive test to determine the existence of the enhancement (such as a sale) provided by the Act, and there is no suggestion of the exclusion of the value increment taken up in the books of the taxpayer, if in fact the value be then existing. The first intimation of that requirement came from the Treasury Regulations; it needs no comment further than to say that if the Act does not authorize or require such a test, as the sole test, the Treasury Department cannot restrict the determination of what is actual surplus to any such narrow basis.

If it be urged that the expression in the Act of one case of property paid in for stock is the exclusion of appreciation in all other instances, under the maxim "expressio unius exclusio alterius," the answer is that this maxim is overborne by the rule which forbids a construction that renders the act invalid if there be any reasonable one which does not. This brings us to the point that it is unreasonably arbitrary and discriminatory, particularly in the matter of a tax based, after all, on what the taxpayer earns on his property, to provide that the incomes of two properties which are of the same kind and are of identical worth on March I, I9I3, for example, and which in the taxable year produce identically the same amount of income, must nevertheless pay taxes at different rates. The "excess profits" tax, in theory at least, proceeds, or should proceed in order to be uniform, on the basis of a percentage on the amount "in excess" of a certain reasonable or standard profit; one owning $\$ 100,000$ worth of property when the law became effective should pay no more than another who at the same time owned $\$ 100,000$ worth of the same property, and no less. Yet by making the test, not the value when the law became effective, but the original cost, the effect, if such cost be the lower, is to confiscate pro tanto the taxpayer's property, for it amounts to pro tanto depriving him of all income therefrom. Is this not the situation alluded to by Mr. Justice White in a case under the Spanish War Tax Law? "If a case should ever arise where an arbitrary and confiscatory exaction is imposed bearing the guise of a progressive or any other form of tax, it will be time enough to consider whether the judicial power can afford a remedy by applying inherent and fundamental principles for the protection of the individual, even though there be no express authority in the constitution to do so..."

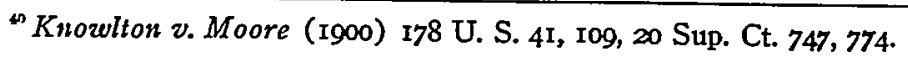

